\title{
PREDICTION OF THE CATASTROPHIC TOOL FAILURE IN HARD TURNING THROUGH ACOUSTIC EMISSION
}

\author{
NAPOVEDOVANJE KATASTROFIČNE POŠKODBE KERAMIČNIH \\ VLOŽKOV PRI STRUŽENJU Z AKUSTIČNO EMISIJO
}

\author{
Mária Čilliková ${ }^{1}$, Branislav Mičieta ${ }^{1}$, Miroslav Neslušan ${ }^{1}$, Robert Čep ${ }^{2}$, \\ Ivan Mrkvica ${ }^{2}$, Jana Petrů ${ }^{2}$, Tomáš Zlámal ${ }^{2}$ \\ ${ }^{1}$ University of Žilina, Faculty of Mechanical Engineering, Univerzitna 8215/1, 01026 Žilina, Slovakia \\ ${ }^{2}$ VŠB-Technical University of Ostrava, Faculty of Mechanical Engineering, 17. listopadu 15, 70833 Ostrava, Czech Republic \\ maria.cilikova@fstroj.uniza.sk \\ Prejem rokopisa - received: 2014-02-07; sprejem za objavo - accepted for publication: 2014-09-03
}

doi:10.17222/mit.2014.029

\begin{abstract}
The paper deals with a new concept for the detection and prediction of the catastrophic tool failure (CTF) of ceramic inserts using an acoustic emission (AE) technique and an associated analysis of the chip formation during hard turning of bearing steel 100Cr6. The suggested method is based on the application of two sensors and the ratios of parameters of the acoustic emission such as AE RMS, AE absolute energy, and AE strength. The specific character of the segmented chips during hard turning is associated with the raw acoustic signals as well as the extracted AE features. The paper indicates that the conventional data processing of acoustic emission signals enables the detection of CTF. Tool wear connected with the cutting edge micro-chipping is related to the slow increase of tool wear (mainly flank wear VB) and stable values of AE features in the normal phase of tool wear. The CTF alters the AE waveforms as well as the course of the AE features. Conventional AE signal processing enables the detection of tool breakage. However, approaching CTF itself cannot be reliably predicted. Hence, a new concept of AE processing based on the ratios of the extracted $\mathrm{AE}$ features obtained in the different frequency ranges is suggested.

Keywords: hard turning, acoustic emission, wear, prediction
\end{abstract}

Članek obravnava nov način odkrivanja in napovedovanja porušitve (CTF) keramičnih vložkov z uporabo tehnike akustične emisije (AE), povezano $\mathrm{z}$ analizo nastanka ostružka med struženjem jekla 100Cr6 za ležaje. Predlagana metoda temelji na uporabi dveh senzorjev in razmerij pri akustični emisiji, kot so AE RMS, absolutna energija AE in AE-moč. Specifična oblika delca ostružka med struženjem je povezana s surovim akustičnim signalom, kot tudi z ločenimi AE-lastnostmi. Članek obravnava, kako konvencionalna obdelava podatkov signalov akustične emisije omogoča določitev CTF. Obraba orodja je povezana s krušenjem rezilnega roba ter s počasnim povečanjem obrabe orodja (večinoma obrabe boka VB) in s stabilnimi vrednostmi AE-lastnosti pri normalni obrabi orodja. CTF spreminja obliko AE-valov, kot tudi AE-lastnosti. Konvencionalna obdelava AE-signalov omogoča odkritje loma orodja. Vendar pa napovedovanje nastanka CTF ni mogoče zanesljivo napovedati. Predlagan je torej nov način obdelave AE, ki temelji na izbranih AE-lastnostih, dobljenih pri različnih območjih frekvenc.

Ključne besede: struženje, akustična emisija, obraba, napovedovanje

\section{INTRODUCTION}

The hard tuning process has found great industrial relevance as a result of recent developments in machine tools (especially cubic boron nitride and ceramics). High flexibility, high removal rates, and the ability to manufacture a complex workpiece geometry in one set are the main advantages of hard turning operations compared to grinding ${ }^{1}$. Furthermore, hard turning makes it possible to avoid coolants and therefore can actually be regarded as an interesting alternative, even from the ecological point of view ${ }^{1,2}$

On the other hand, the main disadvantages of hard turning can be found in the formation of white layers induced in the early stages of tool wear and the high risk of unexpected catastrophic tool failures (CTFs) at the end of the normal phase of tool wear (especially in the case of ceramic inserts ${ }^{3}$. Macro-chipping of the cutting edge should be regarded as a serious problem. CTF can damage the machined surface or tool holder and dramatically alter the tool geometry and corresponding work- piece dimensions. Thus, hard turning operations need the incorporation of a properly proposed monitoring system for the detection or, much better, the prediction of CTF.

Lee, Dornfeld, and Wright ${ }^{4}$ reported on a variety of sensors, each having a certain degree of applicability, for the monitoring of the cutting process. Monitoring techniques based on the implementation of dynamometers, accelerometers, laser interferometers, acoustic emission, and so on were proposed and properly integrated into machine control systems ${ }^{5}$. However, the specific mechanism of chip formation during hard turning means that specific requirements should be met to suggest the proper concept for monitoring hard turning operations.

It is well known that segmented chips are produced during hard turning ${ }^{6,7}$ as a result of the poor plasticity and high hardness and strength of the work material. Thus, thermal softening dominates over strain hardening when the hardness of the work material attains a certain value. It should also be mentioned that the shear instability during chip segmentation is a function, not only of 
the hardness of the work material, but also such aspects as cutting conditions or tool geometry ${ }^{6,7}$. Figure 1 illustrates a segmented chip during the turning of hardened steel 100Cr6. Poulachon and Moisan ${ }^{8}$ published an outstanding study of the different phases of chip segmentation as a series of micrographs. They clearly proved that segment formation starts with a crack initialization near the free surface and its propagation towards the tool tip of the cutting edge (zone Ib; Figure 2). However, crack propagation transforms into a plastically deformed zone where microcracks still occur (zone Ia, Figure 2). The variable chip cross-section is due to the sliding of a segment along the fully cracked surfaces as well as the thinning of the microcracked region during sliding.

Severe plastic deformation can also be found at the tool-chip interface. Thus, the segmented chip is a mixture of zones of extremely high intensity structural transformation located on segment boundaries (narrow white bands) and the nearly untouched structure inside the segment.

In the case of a continuous chip, the rapid shift of the plastic deformation from the actual shear plane to the adjacent plane of the incoming work material is driven by the strain hardening. Therefore, a more pronounced homogeneity of the continuous chip can be found. As a result of the different mechanism of chip formation, conventional soft turning is a process during which the energy needed for chip separation is continuously released, while the chip segmentation represents the cyclic process when the energy accumulated in front of the cutting edge is suddenly emitted when the shear strain near the free surface attains the value which the structure cannot afford to exceed ${ }^{7}$.

This cyclic process is associated with the fluctuation of the cutting force and the corresponding segmentation frequency. This segmentation frequency is a function of the work material properties and the cutting conditions as well as the tool geometry. Shaw and Vyas ${ }^{6}$ reported that the segmentation frequency is about $18 \mathrm{kHz}$ for a cutting speed of $100 \mathrm{~m} \mathrm{~min}^{-1}$ and a feed of $0.28 \mathrm{~mm}$, and the case of carburized steel with a hardness of 62 HRc. Neslušan ${ }^{3}$ reported that the segmentation frequency is strongly dependent on the feed and cutting speed and can be found in the range of $14 \mathrm{kHz}$ to $90 \mathrm{kHz}$. A dynamic

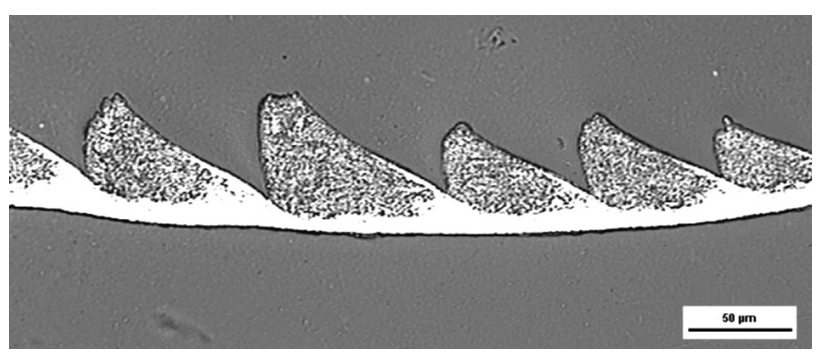

Figure 1: Segmented chip 100Cr6 (hardened $62 \mathrm{HRc}$ ), $v_{\mathrm{c}}=100 \mathrm{~m}$ $\mathrm{min}^{-1}, f=0.09 \mathrm{~mm}$

Slika 1: Segmentirani ostružki 100Cr6 (trdota $62 \mathrm{HRc}, v_{\mathrm{c}}=100 \mathrm{~m}$ $\min ^{-1}, f=0,09 \mathrm{~mm}$ analysis of the processes that fluctuate at a frequency over $25 \mathrm{kHz}$ with the application of conventional accelerometers or dynamometers is difficult to carry out. On the other hand, acoustic emission (AE) techniques enable detection of processes that fluctuate at a frequency over several megahertz.

The AE technique can be successfully adapted for machining operations ${ }^{9}$. This technique is sensitive to events such as dislocation movements, deformation, inclusion fracture, crack propagation, and so on. The major $\mathrm{AE}$ sources ${ }^{10}$ in a metal cutting process are the deformation and fracture of work materials in the cutting zone, deformation, and mainly the fracture of cutting tools, collisions, entanglement, and the breakage of chips.

AE signals can be classified ${ }^{11,12}$ as being either continuous-type or burst-type AE signals. Continuous signals are usually associated with shearing in the primary zone and at the tool-chip and tool-workpiece interfaces, while burst-type AE signals are observed during crack growth in the material, tool fracture, or chip breakage. The major advantage of the AE technique is its high frequency range (much higher than that of the machine vibrations and environmental noises) ${ }^{10}$.

AE techniques were adapted for monitoring turning ${ }^{13}$, milling ${ }^{14}$, drilling ${ }^{15}$, grinding ${ }^{16,17}$, and precision machining ${ }^{18}$. Suggested concepts based on the AE technique are based on the sensitivity of the AE signal to various contact areas and deformation regions. Jemielniak and Otman ${ }^{19}$ reported that the skew and kurtosis extracted from the raw AE signal are more sensitive to CTF than conventional AE signals and AE features. Li and Yuan ${ }^{20}$ gives a brief review of the acoustic emission methods for tool-wear monitoring during turning. Dolinšek and Kopač ${ }^{21}$ investigated the AE signals and associated process

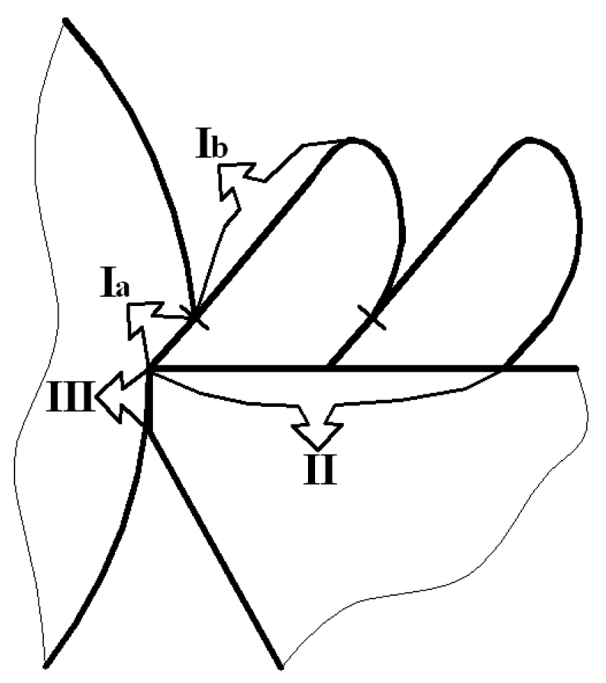

Figure 2: Cutting zone during hard cutting - brief sketch: Iamicrocracked and plastically deformed shear zone, Ib-cracked region, II-tool-chip contact, III-tool-workpiece contact

Slika 2: Območje rezanja med struženjem - shematsko: Ia-plastično deformirano področje striženja z mikrorazpokami, Ib-razpokano področje, II-stik orodje-ostružek, III-stik orodje-obdelovanec 
of tool-wear monitoring. They noticed that tool wear is one of the most influential factors contributing to an increase in the energy of the AE signal. Govekar, Gradišek, and Grabec ${ }^{22}$ suggested a system and methods for the extraction of useful information from signals of multiple sensors (including the $\mathrm{AE}$ technique). Inasaki ${ }^{12}$ reported that continuous-type AE signals are associated with plastic deformations in ductile materials, while burst-type signals are observed during crack growth in the material. Also, many attempts to predict tool wear have been investigated, such as the pattern-classification methodology, fuzzy classifiers, neural networks, and sensor and data fusion methodology, overviewed in. ${ }^{20}$

It is well known that the structure of the workpiece strongly affects the mechanism of chip separation and the machinability of a job. ${ }^{3,6,23,24}$ AE techniques adopted for discontinuous chips are less frequently reported. The chip formation during machining of hardened steel determines the criteria for crack initiation and propagation. Strong elastic waves related to the crack initiation and its propagation during the segment formation can be detected through the AE systems as well as the severe plastic deformation at the tool-chip and tool-workpiece interfaces. Furthermore, regarding segmentation frequencies, the $\mathrm{AE}$ technique is able to detect high-frequency processes emitted by the cutting zone. Therefore, the suggestion of using the AE technique to monitor hard turning operations seems to be reasonable.

Uehara $^{25}$ reported on remarkable patterns in the AE waveforms due to chip segmentation. The amplitude of the acoustic emission varies in accordance with the periodic change of the cutting force. Guo and Ammula ${ }^{26}$ applied $\mathrm{AE}$ for real-time monitoring of the surface damage in hard machining. The results show that $\mathrm{AE}$ signals can be used to monitor surface integrity; specifically $A E_{\text {rms }}$, frequency, and count rate are sensitive to the existence of a white layer and the corresponding tool wear and surface roughness. Barry and Byrne ${ }^{27}$ reported that in comparison to the $A E_{\text {rms }}$ during continuous chip formation, which is between $0.05 \mathrm{~V}$ and $0.1 \mathrm{~V}$, the $A E_{\mathrm{rms}}$ produced during segmented chip formation is at least one order of magnitude greater. In addition to the single AE sensor techniques, multi-sensing techniques were also developed. Axinte et al. ${ }^{28}$ reported the application of the triangulation technique to arrays of acoustic emission sensors for the location of uneven events occurring during machining. The specific character of chip formation in hard turning connected with shear instability, its cyclic character, and mixed processes in the cutting zone (plastic deformation mixed with brittle cracking) suggest that the AE technique should be adapted. Two sensor techniques were suggested and verified. ${ }^{29}$

The application of two different AE sensors is connected with the frequency range of the different processes during the formation of a segmented chip. As was observed, chip formation during hard turning exhibits two different processes. The first is associated with crack initiation on the free surface and its prolongation towards the tool tip (zone Ib, Figure 2). The second type is represented by severe plastic deformation in the shear zone (zone Ia) and at the tool-chip (zone II) and tool-workpiece (III) interfaces. Conventional AE techniques (when turning soft steels) are usually carried out in the frequency ranges corresponding to the frequency range of the WD sensor. However, the process of plastic deformation in the cutting zone during the machining of hardened steel differs from a continuous chip. The cutting process is less stable with the characteristic segmentation frequency (accumulation of energy ahead of the cutting edge and its sudden relaxation in the form of a crack initiated on the free surface). As previously reported,,$^{3,29,30}$ this segmentation frequency does not usually exceed $100 \mathrm{kHz}$ and so it would be difficult to monitor the true dynamics of the cutting process via a WD sensor. Hence, the next D9241A sensor was integrated into the measuring system.

The preliminary studies ${ }^{3,30}$ proved that this suggestion was reasonable. It was found that the peak frequency extracted from the raw AE signal recorded by the D9241A sensor is strongly correlated with the calculated segmentation frequencies and allows the true dynamic, reflecting the cracking process in the shear zone to be detected. The application of the WD sensor does not allow the segmentation frequencies to be detected because the detectable frequency spectrum of the WD sensor lies above all the segmentation frequencies. The instability of the cutting process connected with the chip segmentation (crack initiation and its propagation in the shear zone) does not interfere with AE signals detected by the WD sensor. However, while the character of the raw $\mathrm{AE}$ signal and also the values of the extracted $\mathrm{AE}$ features (such as $A E_{\mathrm{rms}}, A E_{\text {absolute }}$ energy and $A E_{\text {strength }}$ ) obtained from the D9241A sensor stay nearly constant with varying cutting conditions, the magnitude of the AE signals for the WD sensor and the extracted AE features stated above are correlated with the release of energy accumulated ahead of the cutting edge and the corresponding intensity of the transformation processes in the white narrow bands and the more pronounced thinning region of a formed chip. These preliminary studies discussed earlier and carried out at varying cutting speeds (from $25 \mathrm{~m} \mathrm{~min}^{-1}$ to $200 \mathrm{~m} \mathrm{~min}^{-1}$ ) and feeds (from $0.051 \mathrm{~mm}$ to $0.27 \mathrm{~mm}$ ) indicate the correlation among the real intensity of the transformation processes, its dynamics (based on metallographic analyses of the formed chips), and the AE signals recorded by both AE sensors. These analyses also indicated parameters suitable for the evaluation of the deformation processes such as $A E_{\mathrm{rms}}, A E_{\text {absolute }}$ energy and $A E_{\text {strength }}$.

As stated above, a specific mechanism of chip formation takes place during the hard turning. Thus, a specific character of the emitted acoustic waves should be expected. Furthermore, a suitable concept for the detection of the CTF or, much better, its prediction 
should differ from the concept proposed for turning soft steel. Therefore, this paper discusses a specific aspect of AE signals during hard turning and suggests a suitable concept for the CTF prediction.

\section{EXPERIMENTAL SETUP}

The experimental setup is shown in Figure 3. Two commercial piezoelectric AE sensors (D9241A - frequency range from $15 \mathrm{kHz}$ to $180 \mathrm{kHz}$; WD - frequency range from $100 \mathrm{kHz}$ to $1000 \mathrm{kHz}$ ) from Physical Acoustics Corporation were mounted on the top of the tool holder (Figures 3 and 4). Semi-solid high-vacuum grease was used to maintain a good propagation of signals from the tool holder to the sensor. During the experiment, the AE signals were amplified, high passed at $15 \mathrm{kHz}$, low passed at $1000 \mathrm{kHz}$, and then sent through a preamplifier at a gain of $40 \mathrm{~dB}$ to the signalprocessing software package. The signals were sampled in real-time, amplified, digitized, and then fed to the signal processing unit. The AE signals were post-processed using $\mathrm{AE}_{\text {win }}$.

The experimental study was conducted on bearing steel $100 \mathrm{Cr} 6$ of hardness $62 \mathrm{HRc}$ and external diameter $56 \mathrm{~mm}$. The cutting and other conditions were as follows: $v_{\mathrm{c}}=170 \mathrm{~m} \mathrm{~min}^{-1}, f=0.09 \mathrm{~mm}, a_{\mathrm{p}}=0.25 \mathrm{~mm}$, dry

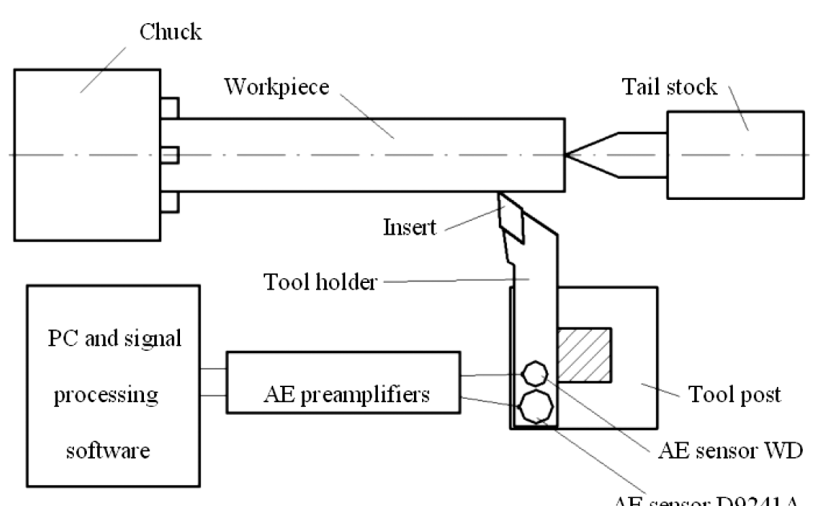

Figure 3: Schematic of the experimental setup

Slika 3: Shematski prikaz eksperimentalnega sestava

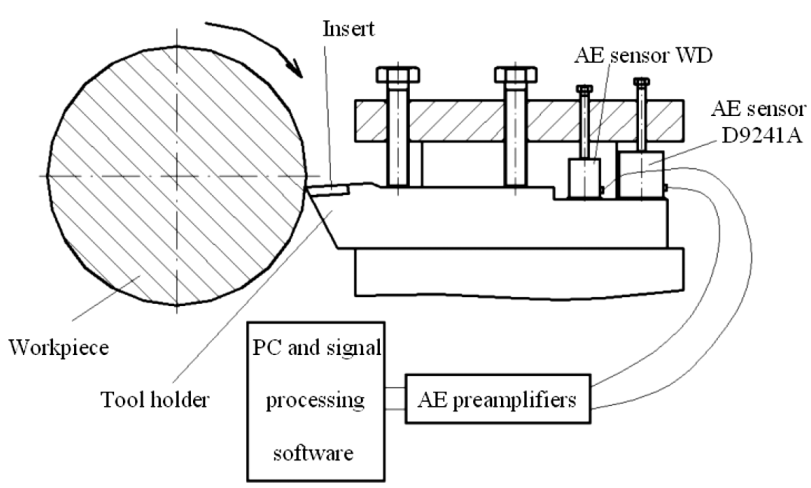

Figure 4: Detail of the sensor placement

Slika 4: Detajl namestitve senzorjev

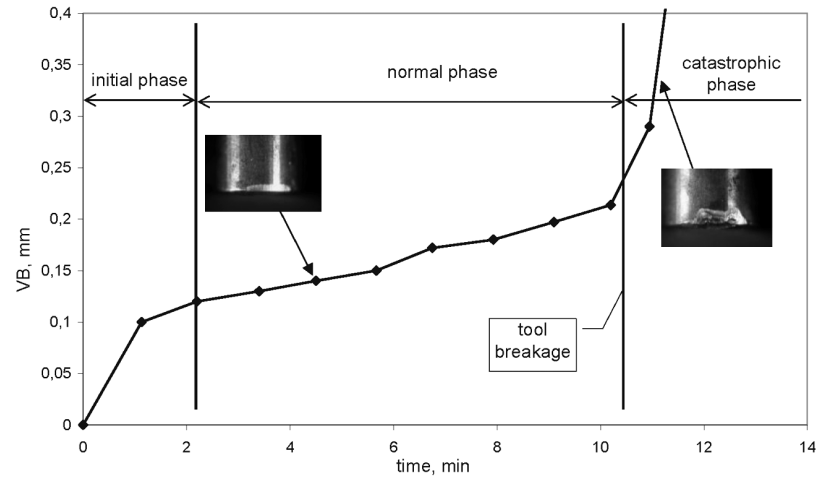

Figure 5: Different phases of tool wear Slika 5: Različne faze obrabe orodja

cutting, CNC Lathe Hurco TM8; the cutting tool was TiC reinforced $\mathrm{Al}_{2} \mathrm{O}_{3}$ ceramic inserts DNGA150408 (TiN coating).

\section{RESULTS}

The specific information connected with the application of two different sensors and their sensitivity to the different processes in the cutting zone can be applied for the monitoring of tool wear. Monitoring of the tool wear for ceramic inserts, especially the prediction of cuttingedge breakage, is a very sophisticated problem. Laboratory and also practical applications of these inserts indicated relatively stable and low-intensity tool wear in the normal phase of tool wear with the following unexpected CTF. The intensity of the tool wear is high in the initial and catastrophic phases of tool wear, as illustrated in Figure 5. While micro-chipping of the cutting edge is a dominant mechanism of tool wear in the initial and normal phases of tool wear, CTF represents tool wear in the form of massive breakage when the shape and tool geometry change dramatically in a very short time period. It is well known that the tool geometry strongly affects the stress and the temperature distribution in the cutting zone and therefore the corresponding chip form, as illustrated in Figures 6 and 7.

A segmented chip forms during the initial and normal phases of tool wear, as shown in Figure 6. It forms on

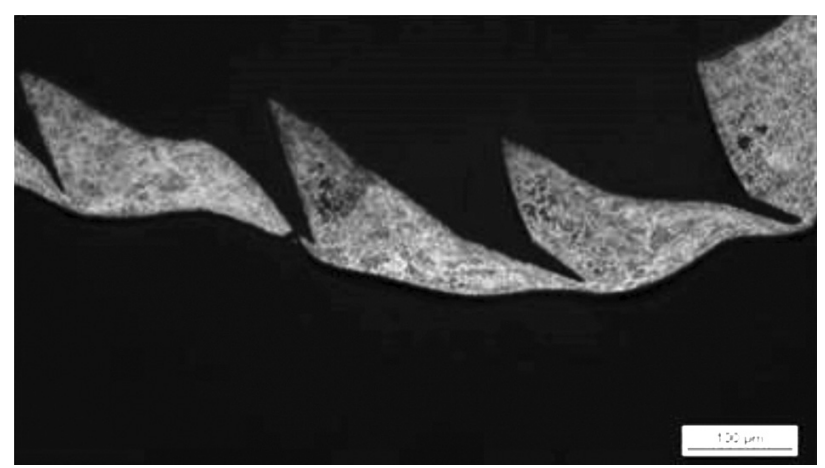

Figure 6: Segmented chip in the normal phase of tool wear Slika 6: Segmentirani ostružki pri normalni fazi obrabe orodja 


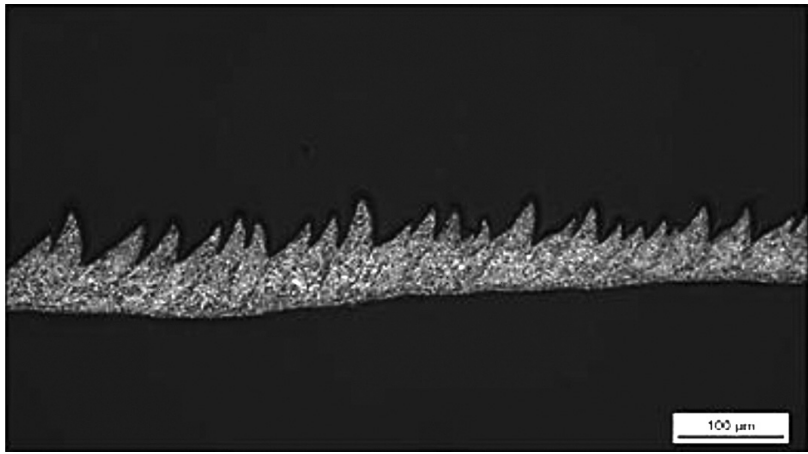

Figure 7: Segmented chip in the catastrophic phase of tool wear Slika 7: Segmentirani ostružki pri katastrofični fazi obrabe orodja

the chamfer in the form of a radius with a highly negative geometry under the high normal stresses induced near the tool tip. In the early stages of tool wear a crater is formed on the tool radius with a rake angle between $-7^{\circ}$ and $-10^{\circ}$, as indicated in Figure 8. However, the CTF usually forms a mainly positive tool geometry and significantly alters the temperature and stress distribution in the cutting zone and the corresponding chip formation (Figures 7 and 9). High compressive stresses near the tool tip can be found when the chip is produced at the

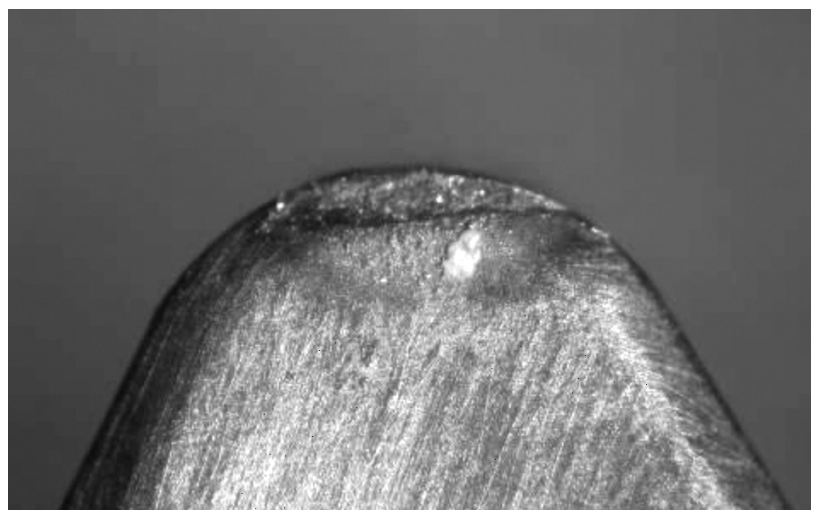

Figure 8: Crater on the cutting-insert radius formed in the initial phase of tool wear

Slika 8: Krater na rezalnem vložku, nastal v začetni fazi obrabe orodja

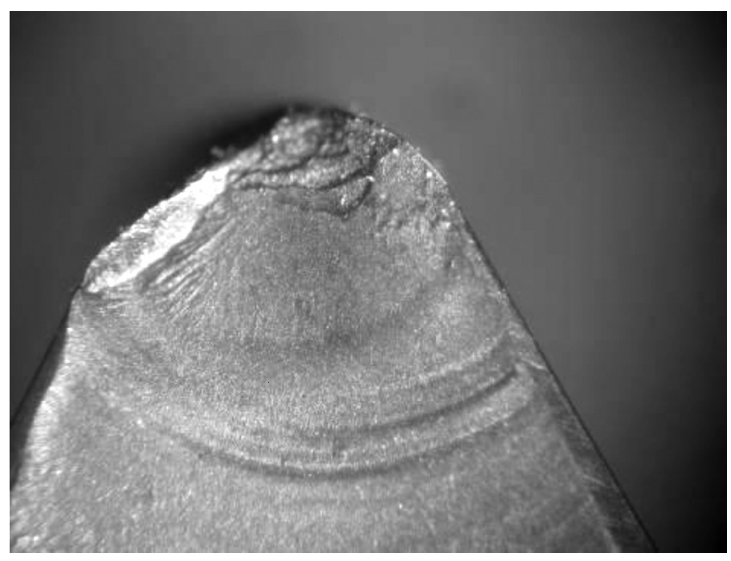

Figure 9: CTF of cutting insert

Slika 9: CTF rezalnega vložka cutting-edge radius. The high compressive stresses ahead of the cutting edge obstruct the early crack initiation. A high portion of energy is accumulated ahead of the cutting edge. A crack on the free surface is initiated when the energy in front of the cutting edge attains its ultimate value. The high energy emitted during brittle cracking corresponds with a more pronounced region of thinning of the produced chip (a longer cracking zone, as illustrated in Figure 6) in the initial and also the normal phase of tool wear. However, the chip becomes more continuous when the tool geometry is strongly altered due to the CTF (Figure 8). The zone of crack propagation $\mathrm{Ib}$ is shorter and the thinning region is reduced.

The character of the chip formed is strongly correlated with the AE signals and the extracted features (parameters). A conventional segmented chip is formed in the initial and normal phases of the tool wear. According to the theory of crack propagation and segment formation, the change in the amplitude of the acoustic emission indicates the change in the sliding velocity at the tool-chip interface and also different phases of the segment formation (the accumulation of energy ahead of the cutting edge and its sudden emission; Figure 10). The observed pulses of the AE signal correspond to the periodic fluctuation (relaxation character) of the cutting process. The signal level of the AE between these pulses is relatively small. During the segmented

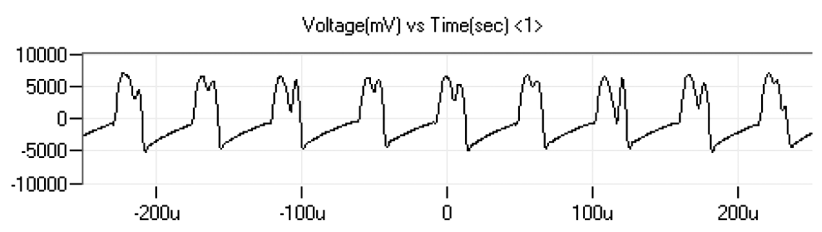

Figure 10: AE-signal in the normal phase of tool wear, D9241A-sensor

Slika 10: AE-signal pri normalni fazi obrabe orodja, D9241A-senzor

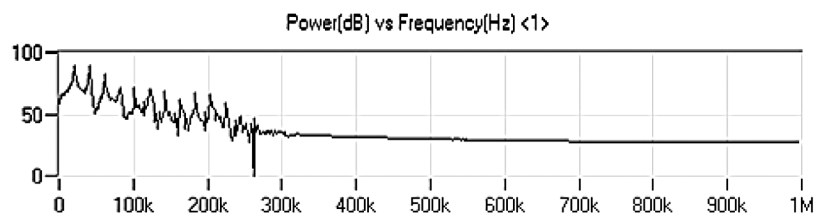

Figure 11: FFT-spectrum for D9241A-sensor in the normal phase of tool wear

Slika 11: FFT-spekter za D9241A-senzor pri normalni fazi obrabe orodja

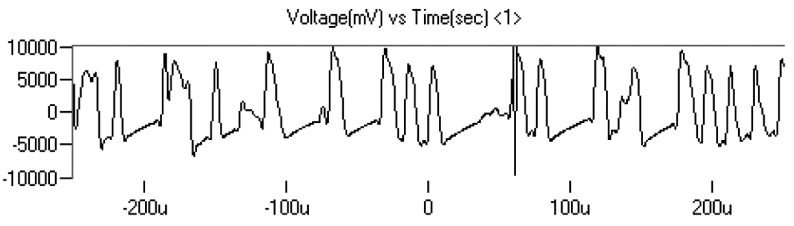

Figure 12: AE-signal in the catastrophic phase of tool wear, D9241Asensor

Slika 12: AE-signal pri katastrofični fazi obrabe orodja, D9241Asenzor 


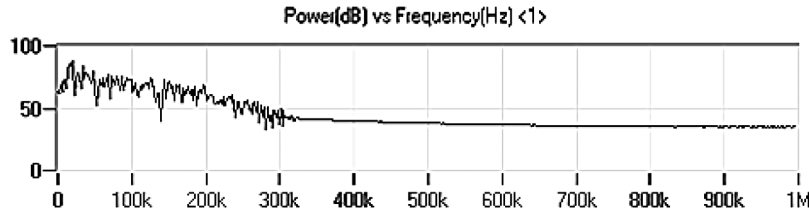

Figure 13: FFT-spectrum for D9241A-sensor in the catastrophic phase of tool wear

Slika 13: FFT-spekter za D9241A-senzor pri katastrofični fazi obrabe orodja

Power(dB) vs Frequency $(\mathrm{Hz})\langle 2\rangle$

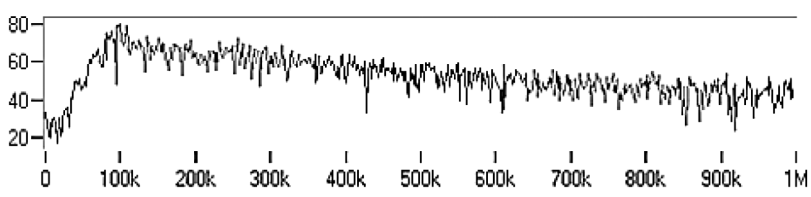

Figure 14: FFT-spectrum for WD-sensor in the normal phase of tool wear

Slika 14: FFT-spekter za WD-senzor pri normalni fazi obrabe orodja

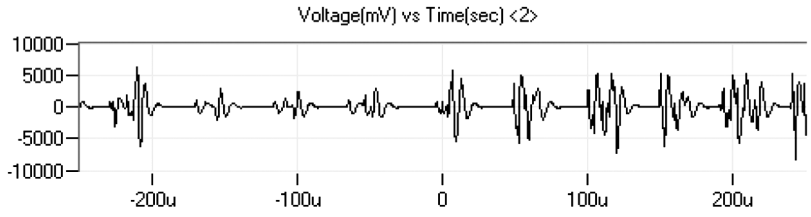

Figure 15: AE-signal in the normal phase of tool wear, WD-sensor Slika 15: AE-signal pri normalni fazi obrabe orodja, WD-senzor

Voltage[mV] vs Time[sec] $\langle 2\rangle$

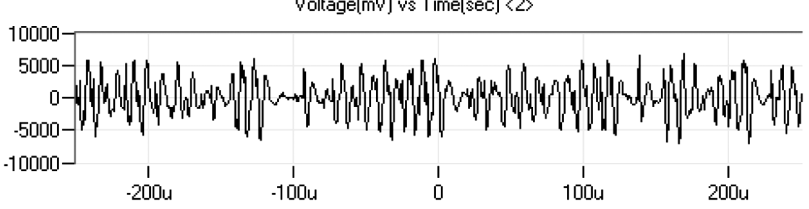

Figure 16: AE-signal in the catastrophic phase of tool wear, WD-sensor

Slika 16: AE-signal pri katastrofični fazi obrabe orodja, WD-senzor

chip formation, the chip slides over the rake face with varying speed.

Figure 10 shows this relaxing and periodic character of the signal in the normal phase of the tool wear and the

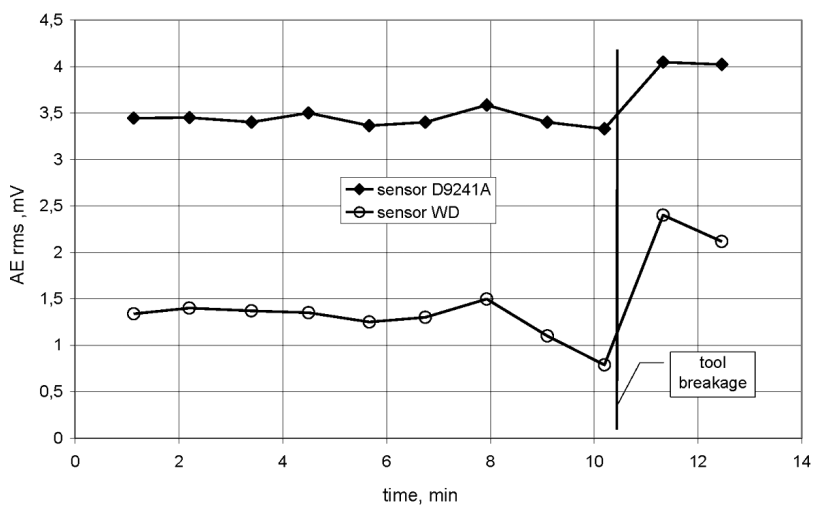

Figure 17: Influence of tool wear on RMS values of the AE Slika 17: Vpliv obrabe orodja na vrednost RMS pri AE related character of the FFT (Fast Fourier Transformation) spectrum (Figure 11) with the periodic peaks in this spectrum (overtones frequencies of the sensor resonance frequency). This character of the FFT spectrum confirms the dominant periodic character of the recorded signal and the ability of the D9241A AE sensor to detect the periodic process typical for the segmented chip formation proved by preliminary experiments. ${ }^{31}$ On the other hand, Figure 12 shows that the character of the AE signal in the catastrophic phase of tool wear is altered. This signal is partially deformed and the periodic character of the AE signal is violated. The irregular character of the AE signal corresponds with the irregular form of the segments produced after the CTF (Figure 7). Moreover, the FFT spectrum of the AE signal is peakfree (Figure 13).

Considering the WD AE sensor, all the segmentation frequencies lie outside the frequency range of this sensor and the relaxing character of the AE signal is missing. The FFT spectrum of the AE signal for the WD sensor is peak-free for all the formed chips (Figure 14). Furthermore, the transformation in the shear zone, where the cracking zone is suppressed and the shear zone is enlarged after the CTF, corresponds with the semi-continuous chip (Figure 15) and also the alteration in the appearance of the AE signal (Figure 16).

The AE features extracted from the raw AE signal plotted in the time scale are illustrated in Figures $\mathbf{1 7}$ to 19. The values of all the parameters for both sensors stay nearly constant in the initial and normal phases of tool wear. Wang and $\mathrm{Liu}^{32}$ carried out the decomposition of the cutting force during hard turning with respect to the chip formation and flank wear. They reported a gradual increase of the shear and the normal force with increasing flank wear and a gentle drop in the forces associated with the chip formation. As the flank wear progresses, the change in the force becomes appreciable. Figures 17 to 19 illustrate that $A E_{\mathrm{rms}}, A E_{\text {absolute }}$ energy and $A E_{\text {strength }}$ vary only a little, despite a gradual increase in the flank wear VB. This indicates that the processes at the tool-workpiece interface play only a minor role

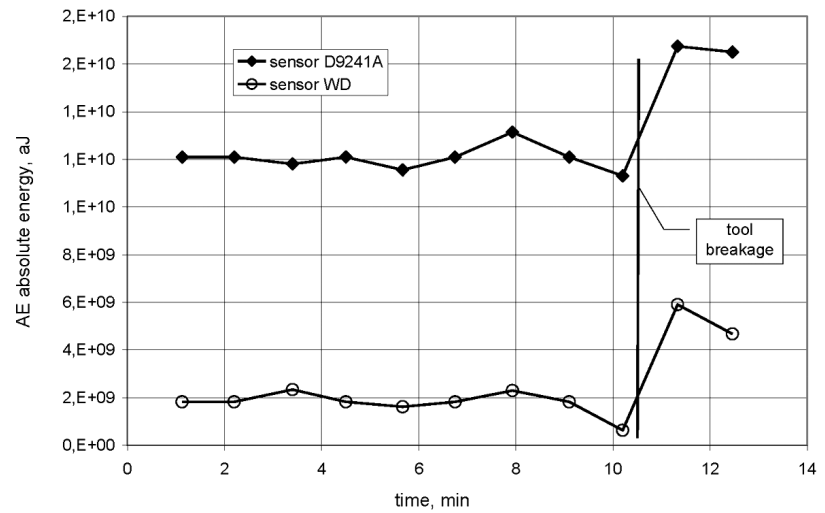

Figure 18: Influence of tool wear on absolute energy of the AE Slika 18: Vpliv obrabe orodja na absolutno energijo AE 


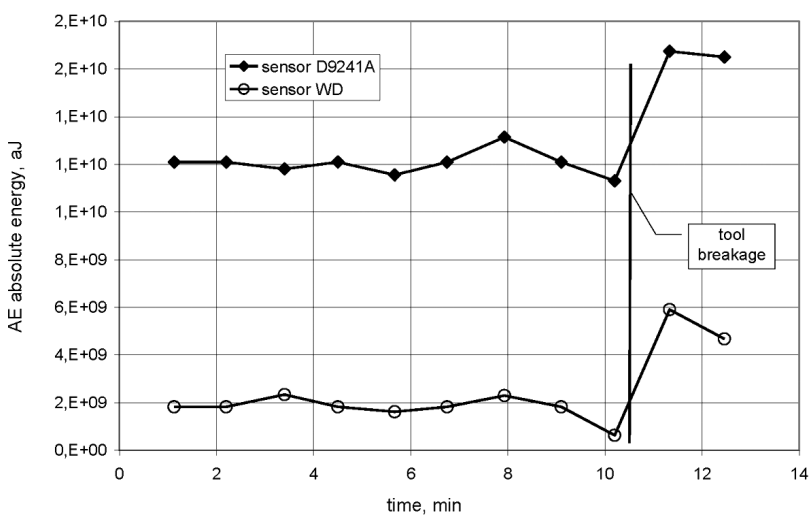

Figure 19: Influence of tool wear on signal strength of the AE Slika 19: Vpliv obrabe orodja na moč signala $\mathrm{AE}$

concerning the AE features and their contribution to the overall AE signals is low.

Since the CTF can be easily recognized (as shown in Figures 17 to 19) the gradual increase of flank wear and the associated process at the tool-workpiece interface are difficult to detect using the AE technique. Furthermore, the AE burst-type signal reflecting micro-chipping as a dominant mechanism of tool wear in the initial and normal phases of tool wear interferes with AE bursting due to cracking in the shear zone. Thus, an alternative approach to the prediction of the CTF has to be suggested. This suggestion can be based on the correlation between the chip form and the corresponding $\mathrm{AE}$ signal (as well as the extracted AE features) since the tool geometry strongly affects the stress and the temperature distribution in the cutting zone and, therefore, the chip appearance.

As illustrated in Figures $\mathbf{1 7}$ and 18, a certain fall of $A E_{\mathrm{rms}}$ and $A E_{\text {absolute }}$ energy can be viewed at the end of the normal phase with a subsequent abrupt increase after the tool breakage. On the other hand, the intensity of these changes differs between the two sensors. While a gentle decrease in the $A E_{\mathrm{rms}}$ value before the CTF for the $9241 \mathrm{~A}$ sensor can be observed (in the time interval from 8 to 10 minutes), a more pronounced decrease is found for the WD sensor. Furthermore, while the increase in the $A E_{\text {rms }}$

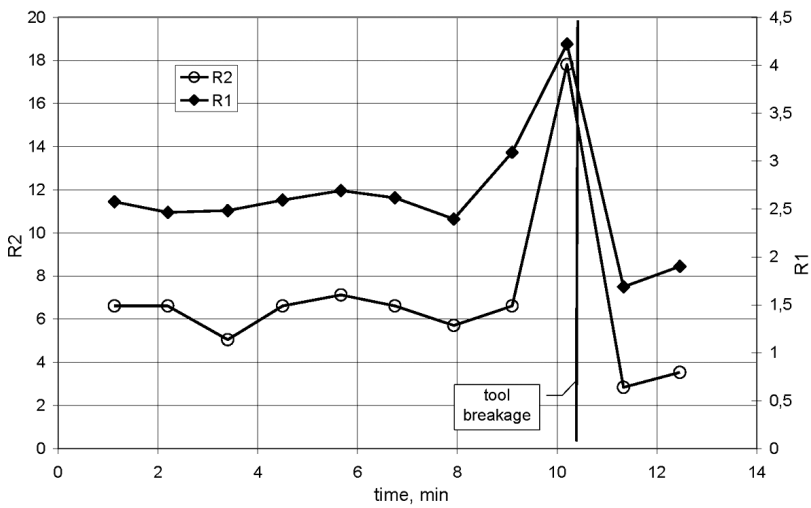

Figure 20: Influence of tool wear on the ratios $R_{1}$ and $R_{2}$ Slika 20: Vpliv obrabe orodja na razmerje $R_{1}$ in $R_{2}$ value after the CTF is only $21 \%$ for the $9241 \mathrm{~A}$ sensor, in the case of the WD sensor the CTF leads to $A E_{\text {rms }}$ values that are twice as high. Thus, the idea of the signal ratio between the features extracted from the different sensors seems to be a suitable quantity that properly expresses the transformation processes in the cutting zone with respect to the tool wear.

Figure 20 indicates the transformation of the $\mathrm{AE}$ features' ratios between the sensors in connection with the transformation of processes in the cutting zone at the end of the normal phase of tool wear. The abrupt increase of the AE features allows the tool breakage itself to be detected. However, poor sensitivity with regard to the CTF prediction is also visible. A reliable CTF prediction can be suggested through a rationing of the extracted features, as indicated by Equations (1) and (2) and illustrated in Figure 20. The significant peaks occur before the tool breakage and these peaks warn of an imminent, approaching CTF. These peaks occur due to the unbalanced sensitivity to the different processes in the cutting zone between WD and D9241A, as discussed above. Moreover, the sensitivity of this approach is significantly higher than that based on the simple fall of AE parameters derived from the WD sensor. The increase in the $R_{1}$ parameter in the time interval from $8 \mathrm{~min}$ to $10 \mathrm{~min}$ is about $77 \%$ and the $R_{2}$ parameter increases two times in the same time interval. The abrupt fall of the $R_{1}$ and $R_{2}$ ratios after the tool breakage is connected with considerable changes in the tool geometry, the corresponding stress and temperature distribution ahead of the cutting edge and the associated chip appearance. This new suggested data processing increases the sensitivity, not only considering the tool-failure prediction, but also considering the CTF detection itself.

The different information can be obtained from $A E_{\text {strength. }}$ Figure 19 shows that the abrupt increase of $A E_{\text {strength }}$ can be found only for the low-frequency sensor, whereas the $A E_{\text {strength }}$ extracted from the high-frequency WD sensor exhibits a remarkable drop. As was reported, the information from WD sensors is mainly correlated with the energy released during the segment formation and corresponds to the length of the cracked region in

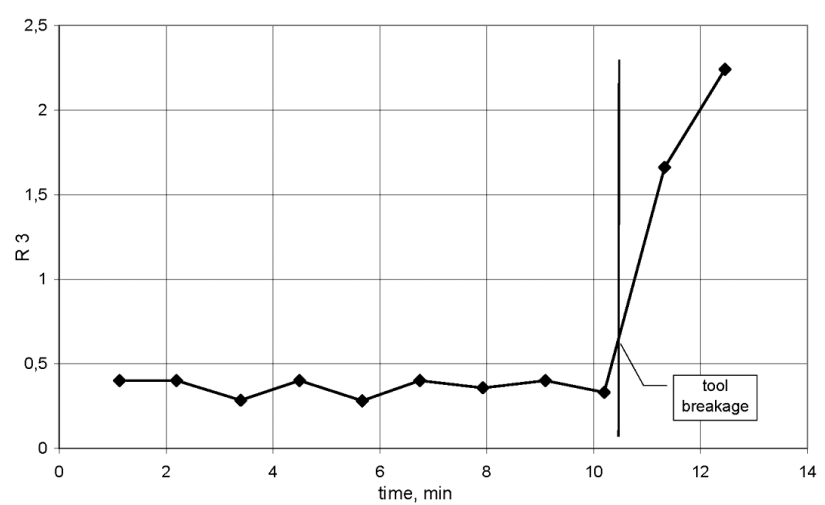

Figure 21: Influence of tool wear on the ratio $R_{3}$ Slika 21: Vpliv obrabe orodja na razmerje $R_{3}$ 
the shearing zone. Being so, the feature $A E_{\text {strength }}$ is a quantity more properly corresponding with the appearance of the obtained chips in the different phases of the tool wear (Figures 6 and 7) than those expressed in $A E_{\mathrm{rms}}$ and $A E_{\text {absolute }}$ energy. Figure 7 shows that the cracked region is reduced after the CTF due to an alteration of the tool geometry (compared to the initial or normal phase of tool wear). The $A E_{\text {strength }}$ of the WD sensor also drops down after the CTF, whereas the $A E_{\text {rms }}$ and $A E_{\text {absolute }}$ energy abruptly increases. A different appearance is also exhibited by the $R_{3}$ ratio (indicated by Equation (3) and illustrated in Figure 21. While nearly constant values of this ratio can be found in the initial and normal phases of tool wear, an abrupt increase due to the CTF failure corresponds with transformations in the processes ahead of the cutting edge (mainly a reduced cracking region and the corresponding decrease of the energy released during the brittle cracking):

$$
\begin{gathered}
R_{1}=A E_{\text {rms (D9241) }} / A E_{\text {rms (WD) }} \\
R_{2}=A E_{\text {absolute energy (D9241) }} / A E_{\text {absolute energy (WD) }} \\
R_{3}=A E_{\text {strength (D9241) }} / A E_{\text {strength (WD) }}
\end{gathered}
$$

\section{CONCLUSIONS}

AE techniques are very sensitive for monitoring the specific processes in the cutting zone. The formation of a segmented chip during hard turning is a very specific example of different processes in the cutting zone. This aspect indicates some conclusions connected with this experimental study.

- The application of two AE sensors with different frequency ranges makes it possible to detect the different processes in the cutting zone.

- While the low-frequency AE sensor 9241A allows the real dynamic character of chip segmentation to be detected, the high-frequency $\mathrm{AE}$ sensor $\mathrm{WD}$ is sensitive to the real intensity of the deformation processes in the different zones.

- Both sensors make it possible to detect tool breakage through the conventional parameters derived from the $\mathrm{AE}$ signals, and the AE signals reflect the transformation in the formation of the chip produced.

- The sensitivity of the tool-breakage prediction through the conventional parameters derived from the $\mathrm{AE}$ signals is poor.

- The ratios of $\mathrm{AE}$ features such as $A E_{\mathrm{rms}}$ and $A E_{\text {absolute }}$ energy between sensors change at the end of the normal phase of the tool wear. This transformation forms peaks that occur before the tool breakage, providing a warning of imminent tool failure.

- The ratio of $A E_{\text {strength }}$ between the sensors changes after the CTF. The $A E_{\text {strength }}$ itself more properly expresses the true intensity of the processes during chip separation than the $A E_{\mathrm{rms}}$ and $A E_{\text {absolute }}$ energy.

- The results of the experimental work presented in this paper were verified by many similar experiments carried out under different cutting conditions. A certain difference was found at low cutting depths, but the signals ratio also significantly increases the sensitivity for the detection of tool breakage and the prediction of tool failure.

\section{Acknowledgement}

This article was edited under the financial support of KEGA projects n. 005ŽU - 4/2014, 009ŽU - 4/2014.

\section{REFERENCES}

${ }^{1}$ H. K. Tönshoff, C. Arendt, R. B. Mor, Cutting of Hardened Steel, CIRP, 49 (2000), 547-564, doi:10.1016/S0007-8506(07)63455-6

${ }^{2}$ S. J. Heo, Environmentally conscious hard turning of cemented carbide materials on the basis of micro-cutting, J. of Mech. Sci. and Technol., 22 (2008), 1383-1390, doi:10.1007/s12206-008-0411-z

${ }^{3}$ M. Neslušan, Hard turning, Edis, Žilina 2010

${ }^{4}$ Y. Lee, D. A. Dornfeld, P. K. Wright, Open Architecture Based Framework in Integrated Precision Machining System, IMECE Anaheim, 1998

${ }^{5}$ M. Teti, K. Jemielniak, G. O. Donnell, D. Dornfeld, Advanced monitoring of machining operations, CIRP, 59 (2010), 717-739, doi:10.1016/j.cirp.2010.05.010

${ }^{6}$ M. C. Shaw, A. Vyas, The mechanism of chip formation with hard turning steel, CIRP, 47 (1998), 77-82, doi:10.1016/S0007-8506(07) 62789-9

${ }^{7}$ K. Nakayama, M. Arai, T. Kanda, Machining characteristics of hardened steels, CIRP, 37 (1988), 89-92, doi:10.1016/S00078506(07)62789-9

${ }^{8}$ G. Poulachon, A. Moisan, Contribution to the study of the cutting mechanism during high speed machining of hardened steel, CIRP, 47 (1998), 73-76, doi:10.1016/S0007-8506(07)62788-7

${ }^{9}$ H. K. Tönshoff, M. Jung, S. Mannel, W. Rietz, Using acoustic emission signals for monitoring of production processes, Ultrasonics, 37 (2000), 681-686, doi:10.1016/S0041-624X(00)00026-3

${ }^{10}$ D. A. Dornfeld, Acoustic emission in monitoring and analysis in manufacturing, Proceedings of AE Monitoring, 14 (1984), 124-131

${ }^{11}$ D. A. Dornfeld, Manufacturing process monitoring and analysis using acoustic emission, Journal of Acoustic Emission, 4 (1985), 123-126

${ }^{12}$ I. Inasaki, Application of acoustic emission sensor for monitoring machining processes, Ultrasonics, 36 (1998), 273-281, doi:10.1016/ S0041-24X(97)00052-8

${ }^{13}$ J. Barry, G. Byrne, D. Lennon, Observations on chip formation and acoustic emission in machining Ti-6Al-4V alloy, International Journal of Machine Tools and Manufacture, 41 (2001) 7, 1055-1070, doi:10.1016/S0890-6955(00)00096-1

${ }^{14}$ I. Marinescu, D. A. Axinte, A critical analysis of effectiveness of acoustic emission signals to detect tool and workpiece malfunctions in milling operations, International Journal of Machine Tool and Manufacture, 48 (2008), 1148-1160, doi:10.1016/j.ijmachtools. 2008.01.011

${ }^{15}$ M. P. Gómez, A. M. Hey, J. E. Ruzzante, C. E. D’Attellis, Tool wear evaluation in drilling by acoustic emission, Physica Procedia, 3 (2010), 819-825, doi:10.1016/j.phpro.2010.01.105

${ }^{16}$ D. E. Lee, I. Hwang, C. M. O. Valente, J. F. G. Oliveira, D. A. Dornfeld, Precision manufacturing process monitoring with acoustic emission, International Journal of Machine Tool and Manufacture, 46 (2006), 176-188, doi:10.1016/j.ijmachtools.2005.04.001

${ }^{17}$ R. Babel, P. Koshy, M. Weiss, Acoustic emission spikes at workpiece edges in grinding: Origin and applications, International Journal of Machine Tool and Manufacture, 63 (2013), 96-101, doi:10.1016/ j.ijmachtools.2012.08.004 


\section{M. ČILLIKOVÁ et al.: PREDICTION OF THE CATASTROPHIC TOOL FAILURE OF CERAMIC INSERTS ...}

${ }^{18}$ S. Min, J. Lidde, N. Raue, D. Dornfeld, Acoustic emission based tool contact detection for ultra-precision machining, CIRP, 60 (2011), 141-144, doi:10.1016/j.cirp.2011.03.079

${ }^{19} \mathrm{~K}$. Jemielniak, O. Otman, Tool failure detection based on analysis of acoustic emission signals, Journal of Material Processing Technology, 76 (1998), 192-197, doi:10.1016/S0924-0136(97)00379-8

${ }^{20}$ X. Li, Z. Yuan, Tool wear monitoring with wavelet packet transform-fuzzy clustering method, Wear, 219 (1998), 145-154, doi:10.1016/S0043-1648(98)00165-3

${ }^{21}$ S. Dolinšek, J. Kopač, Acoustic emission signals for tool wear identification, Wear, 225-229 (1999), 295-303, doi:10.1016/S00431648(98)00363-9

${ }^{22}$ E. Govekar, J. Gradišek, I. Grabec, Analysis of acoustic emission signals and monitoring of machining processes, Ultrasonics, 38 (2000), 598-603, doi:10.1016/S0041-624X(99)00126-2

${ }^{23} \mathrm{M}$. Sekulič et al., Influence of material properties on the machinability in face milling, Mater. Tehnol., 46 (2012) 6, 601-606

${ }^{24}$ O. Topku, M. Übeyli, A. Acir, Effect of the martensite volume fraction on the machining of a dual - phase steel using a milling operation, Mater. Tehnol., 45 (2011) 2, 145-150

${ }^{25} \mathrm{~K}$. Uehara, Identification of Chip Formation Mechanism through Acoustic Emission Measurements, CIRP, 33 (1974), 71-74, doi:10.1016/S0007-8506(07)61382-1

${ }^{26}$ Y. B. Guo, S. C. Ammula, Real-time acoustic emission monitoring for surface damage in hard machining, International Journal of Machine Tool and Manufacture, 45 (2005), 1622-1627, doi:10.1016/ j.ijmachtools.2005.02.007
${ }^{27}$ J. Barry, G. Byrne, Chip Formation, Acoustic Emission and Surface White Layers in Hard Machining, CIRP, 51 (2002), 65-70, doi:10.1016/S0007-8506(07)61467-X

${ }^{28}$ D. A. Axinte, D. R. Natarajan, N. Z. Gindy, An approach to use an array of three acoustic emission sensors to locate uneven events in machining - Part 1: method and validation, International Journal of Machine Tool and Manufacture, 45 (2005), 1605-1613, doi:10.1016/ j.ijmachtools.2005.02.005

${ }^{29}$ M. Šípek, M. Neslušan, M. Čilliková, Analysis of segmented chip when hard turning through acoustic emission, Manufacturing Technology, 14 (2010), 254-257

${ }^{30}$ M. Neslušan, I. Mrkvica, R. Čep, M. Čilliková, Influence of cutting speed on intensity of the plastic deformation during hard turning, Mater. Tehnol., 47 (2013) 6, 745-755

${ }^{31}$ B. Karpuschewski, K. Schmidt, J. Prilukova, J. Beňo, I. Maňková, N. T. Hieu, Influence of tool edge preparation on performance of ceramic tool inserts when hard turning, Journal of Materials Processing Technology, 213 (2013), 1978-1988, doi:10.1016/ j.jmatprotec.2013.05.016

${ }^{32}$ J. Y. Wang, C. R. Liu, The effect of tool flank wear on the heat transfer, thermal damage and cutting mechanics in finishing hard turning, CIRP, 48 (1999), 53-56, doi:10.1016/S0007-8506(07) 63130-8 